\title{
7 \\ General Comment of the HRC on the rights of minorities
}

\author{
ICCPR General Comment 23
}

The rights of minorities

(Article 27)

(Fiftieth session, 1994)

1 Article 27 of the Covenant provides that, in those States in which ethnic, religious or linguistic minorities exist, persons belonging to these minorities shall not be denied the right, in community with the other members of their group, to enjoy their own culture, to profess and practise their own religion, or to use their own language. The Committee observes that this article establishes and recognises a right which is conferred on individuals belonging to minority groups and which is distinct from, and additional to, all the other rights which, as individuals in common with everyone else, they are already entitled to enjoy under the Covenant.

2 In some communications submitted to the Committee under the Optional Protocol, the right protected under article 27 has been confused with the right of peoples to self-determination proclaimed in article 1 of the Covenant. Further, in reports submitted by States' parties under article 40 of the Covenant, the obligations placed upon States' parties under article 27 have sometimes been confused with their duty under article 2.1 to ensure the enjoyment of the rights guaranteed under the Covenant without discrimination and also with equality before the law and equal protection of the law under article 26.

3.1 The Covenant draws a distinction between the right to self-determination and the rights protected under article 27. The former is expressed to be a right belonging to peoples and is dealt with in a separate part (Part I) of the Covenant. Self-determination is not a right cognisable under the Optional Protocol. Article 27, on the other hand, relates to rights conferred on individuals as such and is included, like the articles relating to other personal rights 


\section{Annexes}

conferred on individuals, in Part III of the Covenant and is cognisable under the Optional Protocol. ${ }^{1}$

3.2 The enjoyment of the rights to which article 27 relates does not prejudice the sovereignty and territorial integrity of a State party. At the same time, one or other aspect of the rights of individuals protected under that article - for example, to enjoy a particular culture - may consist in a way of life which is closely associated with territory and use of its resources. ${ }^{2}$ This may particularly be true of members of indigenous communities constituting a minority.

4 The Covenant also distinguishes the rights protected under article 27 from the guarantees under articles 2.1 and 26. The entitlement, under article 2.1, to enjoy the rights under the Covenant without discrimination applies to all individuals within the territory or under the jurisdiction of the State whether or not those persons belong to a minority. In addition, there is a distinct right provided under article 26 for equality before the law, equal protection of the law, and non-discrimination in respect of rights granted and obligations imposed by the States. It governs the exercise of all rights, whether protected under the Covenant or not, which the State party confers by law on individuals within its territory or under its jurisdiction, irrespective of whether they belong to the minorities specified in article 27 or not. ${ }^{3}$ Some States' parties who claim that they do not discriminate on grounds of ethnicity, language or religion, wrongly contend, on that basis alone, that they have no minorities.

5.1 The terms used in article 27 indicate that the persons designed to be protected are those who belong to a group and who share in common a culture, a religion and/or a language. Those terms also indicate that the individuals designed to be protected need not be citizens of the State party. In this regard, the obligations deriving from article 2.1 are also relevant, since a State party is required under that article to ensure that the rights protected under the Covenant are available to all individuals within its territory and subject to its jurisdiction, except rights which are expressly made to apply to citizens, for example, political rights under article 25. A State party may not, therefore, restrict the rights under article 27 to its citizens alone.

5.2 Article 27 confers rights on persons belonging to minorities which 'exist' in a State party. Given the nature and scope of the rights envisaged under that article, it is not relevant to determine the degree of permanence that the term

${ }^{1}$ See Official Records of the General Assembly, Thirty-ninth Session, Supplement No. 40 (A/39/40), annex VI, General Comment No. 12 (21) (article 1), also issued in document CCPR/C/21/Rev.1; ibid., Forty-fifth Session, Supplement No. 40 (A/45/40), vol. II, annex IX, sect. A, Communication No. 167/1984 (Bernard Ominayak, Chief of the Lubicon Lake Band v Canada), views adopted on 26 March 1990.

${ }^{2}$ See ibid., Forty-third Session, Supplement No. 40 (A/43/40), annex VII, sect. G, Communication No. 197/1985 (Kitok v Sweden), views adopted on 27 July 1988.

${ }^{3}$ See ibid., Forty-second Session, Supplement No. 40 (A/42/40), annex VIII, sect. D, Communication No. 182/1984 (F. H. Zwaan-de Vries v The Netherlands), views adopted on 9 April 1987; ibid., sect. C, Communication No. 180/1984 (L. G. Danning $v$ The Netherlands), views adopted on 9 April 1987. 
'exist' connotes. Those rights simply are that individuals belonging to those minorities should not be denied the right, in community with members of their group, to enjoy their own culture, to practise their religion and speak their language. Just as they need not be nationals or citizens, they need not be permanent residents. Thus, migrant workers or even visitors in a State party constituting such minorities are entitled not to be denied the exercise of those rights. As any other individual in the territory of the State party, they would, also for this purpose, have the general rights, for example, to freedom of association, of assembly, and of expression. The existence of an ethnic, religious or linguistic minority in a given State party does not depend upon a decision by that State party but requires to be established by objective criteria.

5.3 The right of individuals belonging to a linguistic minority to use their language among themselves, in private or in public, is distinct from other language rights protected under the Covenant. In particular, it should be distinguished from the general right to freedom of expression protected under article 19. The latter right is available to all persons, irrespective of whether they belong to minorities or not. Further, the right protected under article 27 should be distinguished from the particular right which article 14.3 (f) of the Covenant confers on accused persons to interpretation where they cannot understand or speak the language used in the courts. Article 14.3 (f) does not, in any other circumstances, confer on accused persons the right to use or speak the language of their choice in court proceedings. ${ }^{4}$

6.1 Although article 27 is expressed in negative terms, that article, nevertheless, does recognise the existence of a 'right' and requires that it shall not be denied. Consequently, a State party is under an obligation to ensure that the existence and the exercise of this right are protected against their denial or violation. Positive measures of protection are, therefore, required not only against the acts of the State party itself, whether through its legislative, judicial or administrative authorities, but also against the acts of other persons within the State party.

6.2 Although the rights protected under article 27 are individual rights, they depend in turn on the ability of the minority group to maintain its culture, language or religion. Accordingly, positive measures by States may also be necessary to protect the identity of a minority and the rights of its members to enjoy and develop their culture and language and to practise their religion, in community with the other members of the group. In this connection, it has to be observed that such positive measures must respect the provisions of articles 2.1 and 26 of the Covenant both as regards the treatment between different minorities and the treatment between the persons belonging to them and the remaining part of the population. However, as long as those measures are aimed at correcting conditions which prevent or impair the enjoyment of the

${ }^{4}$ See ibid., Forty-fifth Session, Supplement No. 40, (A/45/40), vol. II, annex X, sect. A, Communication No. 220/1987 (T. K. v France), decision of 8 November 1989; ibid., sect. B, Communication No. 222/1987 (M. K. v France), decision of 8 November 1989. 


\section{Annexes}

rights guaranteed under article 27, they may constitute a legitimate differentiation under the Covenant, provided that they are based on reasonable and objective criteria.

7 With regard to the exercise of the cultural rights protected under article 27, the Committee observes that culture manifests itself in many forms, including a particular way of life associated with the use of land resources, especially in the case of indigenous peoples. That right may include such traditional activities as fishing or hunting and the right to live in reserves protected by law. ${ }^{5}$ The enjoyment of those rights may require positive legal measures of protection and measures to ensure the effective participation of members of minority communities in decisions which affect them.

The Committee observes that none of the rights protected under article 27 of the Covenant may be legitimately exercised in a manner or to an extent inconsistent with the other provisions of the Covenant.

9 The Committee concludes that article 27 relates to rights whose protection imposes specific obligations on States' parties. The protection of these rights is directed towards ensuring the survival and continued development of the cultural, religious and social identity of the minorities concerned, thus enriching the fabric of society as a whole. Accordingly, the Committee observes that these rights must be protected as such and should not be confused with other personal rights conferred on one and all under the Covenant. States' parties, therefore, have an obligation to ensure that the exercise of these rights is fully protected and they should indicate in their reports the measures they have adopted to this end.

${ }^{5}$ See notes 1 and 2 above, Communication No. 167/1984 (Bernard Ominayak, Chief of the Lubicon Lake Band v Canada), views adopted on 26 March 1990, and Communication No. 197/1985 (Kitokv Sweden), views adopted on 27 July 1988. 